\title{
Beyond the dominant discourse of human rights
}

\author{
Além do discurso dominante dos \\ direitos humanos
}

Edna Raquel Hogemann ${ }^{1}$

Vicente Paulo Barretto ${ }^{2}$

\begin{abstract}
It promotes a critical reflection on the theoretical foundations of the dominant discourse of human rights, from a relativistic role of European Modernity seeking afford to see ideas, struggles, thoughts and peripheral stories as a first step to reshape this discourse whose effectiveness remains questioned, in practice. It assumes that the theoretical foundations of the dominant discourse of human rights has been the subject of extensive research, which, at first, might suggest that the discussion on this subject was already exhausted and therefore does not deserve greater contributions. These conceptions about the human rights foundations, usually rest in some incontrovertible premises. This discourse, for reasons that will be presented, was designed as a hegemonic discourse. The theoretical reference counter-hegemonic is based on Makau Mutua and Sousa Santos' thinking. The general objective of the authors is to generate a critical reflection of this dominant conception of human rights, whose contours do not permit the conjecture of new discourses, from the signaling paths that encourage the (re) construction of other speeches consider histories and cultures through otherness, interdependence and human mutualism. This is a research with descriptive exploratory and qualitative, which seeks to achieve as a result of an interdisciplinary understanding of issues related to the formulation of human rights policies in the contemporary world, which should include strengthening the respect for these, many times overlooked or frankly disrespected by the modern state.
\end{abstract}

\section{KEYWORDS}

Human Rights; hegemonic discourse; interdependence; human mutualism.

\section{RESUMO}

Promover uma reflexão crítica sobre os fundamentos teóricos do discurso dominante dos direitos humanos, a partir de um papel relativista da modernidade europeia, buscando permitir ver ideias, lutas, pensamentos e histórias periféricas como

1 Professora permanente do PPGD em Direito, da UNESA. Professora Adjunta do Curso de Direito da UNIRIO.

2 Professor decano do PPGD/UNESA, professor decano do PPGD/UNISINOS. 
um primeiro passo para remodelar este discurso cuja eficácia, em prática, permanece questionada. Assume-se que os fundamentos teóricos do discurso dominante dos direitos humanos tem sido objeto de extensa pesquisa, que, a princípio, poderia sugerir que a discussão sobre este assunto já estava esgotada e, portanto, não mereceria uma maior contribuição. Estas concepções sobre as bases dos direitos humanos, geralmente repousam em algumas premissas incontestáveis. Esse discurso, por razões que serão apresentadas, foi concebido como um discurso hegemônico. A referência teórica contrahegemônica está baseada em Makau Mutua e no pensamento Sousa Santos. O objetivo geral dos autores é gerar uma reflexão crítica dessa concepção dominante dos direitos humanos, cujos contornos não permitem a conjectura de novos discursos e de caminhos que estimulem a (re) construção de outros discursos que considere as histórias e culturas através da alteridade, interdependência e mutualismo humano. Esta é uma pesquisa exploratória descritiva e qualitativa, que procura alcançar resultado através de uma compreensão interdisciplinar de questões relacionadas com a formulação de políticas de direitos humanos no mundo contemporâneo, que deve incluir o fortalecimento do respeito para estes, muitas vezes negligenciados ou claramente desrespeitados pelo Estado moderno.

\section{PALAVRAS-CHAVE}

Direitos humanos; discurso hegemônico; interdependência; mutualismo humano.

\section{INTRODUCTION}

Human rights are considered either as a coherent reflection with liberal thought, now as an objective consequence of the political struggles in the European scenario of modernity, with the detonator element classical liberalism and its individual liberty and formal equality ideas. That is why the genesis of human rights reflects nothing or appropriates the history and rationale of non-Western peoples. This speech, for reasons that will be presented throughout this trial, has established itself as a hegemonic discourse, but, gradually, has been questioned. From the theoretical reflections of authors such as Makau Mutua and Sousa Santos, the aim is to made a critical question to this dominant conception of human rights, which in reality does not guarantees them full effectiveness, which is why a new proposition is necessary and / or alternative discourses, from the indication of ways that encourage the (re) construction of these other discourses, beyond the current hegemonic discursive reading, considering histories and cultures through otherness, interdependence and human mutualism.

Interest in the reflection comes as the ineffectiveness of the realization of human rights, and arises about it, although the theoretical foundations of human rights already have made in topic widely researched, that does not mean it does not deserve other looks, because issues related to ineffectiveness when the normative application of human rights are to promote further deepening. The proposal is, from a retrospective of philosophical and political context in which was born the notion of "human rights", pointing out its foundations, and inherent in its historical effectiveness issues, taking into account the contribution of the natural law and legal positivism, rational modernity, logical and positivist in a universe dominated by the rule of law. It also proposes to place the speech 
of human rights in the current socio-political context of crisis of the reason fundamentals, foundational paradigm and structuring of society in need of a change.

\section{HUMAN RIGHTS AND THE MODERN EUROPEAN LIBERAL THOUGHT}

When dealing with the history of human rights, as designed, should be kept in view the conjunction of power struggles waged between nobility and bourgeoisie, the English political and religious struggles, French, American of the seventeenth and eighteenth centuries, with the theoretical tradition of rationalist thought of modernity. All the pre-modern period was founded on the notion of communitas as a natural order placed, a universal community, predetermined and abiding ontological-metaphysical character, domain of the "Being".

Modernity opens a new understanding, product of a long preparation, at the end of the Middle Ages, and seated in cultural, philosophical, social and historical basis since antiquity. This new understanding lies the community as a society built on a contractual basis, as a result of experience and cultural commitment of men holders of a rationality engaged in a voluntary agreement.

The cause and a consequence of this transformation lie in the emergence of the individual person's position endowed with subjectivity overcoming the conceptions of ancient Greece and Christianity of the Middle Ages, centered respectively on the polis and the "universal church". The person's figure as an essential value of all an ethical-legal complex has become solid so only with the union of the ancient philosophies, particularly the Stoic tradition, with an incipient Christian theology.

In the Renaissance period, the person setting received a new element, the human dignity, exalted and studied by the thinkers of the time, setting up very foundation of the struggle for rights, especially political, driven in the following centuries. These new ideas led to the occurrence of a substantial change in Science and Philosophy. During this period, the humanists lie their questions on men and in the world they live; questioning mainly the fate of men, and spreading the concept according to which, in addition to the substance, there is within man this spiritual element, immaterial.

Enlightenment will elaborate their ideas on society, state and law, based on the European universe, regarded as a universal model. The legal discourse, for example, was built taking into account the design on the progress and evolution. The state of nature was consolidated as the legal and political archetype itself of colonized peoples (barbarians), while the civil status was the privilege of the society that the "subject of knowledge" belonged, namely the European (hero - savior) colonizer, Enlightenment thinker who invades and plunders "colonizing" a subaltern process of local knowledge considered "barbarians."

In parallel, the Enlightenment promotes respect and worship of man as master of his own destiny, having as reference a fully rational worldview, emphasizing the principle of freedom and individual autonomy.

The triumph of individualistic view precisely coincides with the inaugural events of positivation of human rights: from the English Bill of Rights, through the American Declaration of Independence of 1776, to the Declaration of the Rights of Man and of the Citizen, proclaimed in France in 1789, who dedicated civil liberties and added also the legal expression of the Enlightenment project based on the individual emancipation of 
promise forms of political oppression, the scope of human rights has expanded and was revealing the economic and social rights.

Human rights were born in modern political discourse as a necessary prerequisite for the autonomy of individuals in the face of the state, marked by absolutist governments in Europe in capitalist expansion. The modern liberal ideology embodied in the Declaration takes as its starting point the natural rights of man as established in the theory of social contract, justified by rational nature of man, the service of a liberal and bourgeois project.

The paradigm of modernity is rooted in reason, considered as subordinate to the empirical-rational method, that is, what Castoriadis (1987) calls as rational procedure entirety-identity logic, in accordance to the classical principles of Aristotelian logic, as submission rules induction and deduction, and especially, to the principles of contradiction, of identity and of the excluded.

This rationality make men master and proprietor of himself (jus in se ipsum), as well as their choices, that is why it would be a violence to prevent the free man to use his reason and, to the extent that the natural rights come from hypothesis (real or imagined) of a pre-social state or nature, its founding anthropological conception is that the individual exists and remains alone and society is not the time to realization of the human, making otherness a purely formal sense, when not something inconvenient.

However, if on the one hand the enhancement of the idea of the power of the human being as the subject appears as the basis of equal rights among citizens, even when outside the nobility or clergy, on the other, and paradoxically, this promotes the subjectivity annihilation, insofar as it was established a so-called universal knowledge legal starting from the design according to which it would be possible to have knowledge of subjects and neutral apart time and space.

This process flowed in waves of an exaggerated rationalism and excessive Cartesian world view, in which reality is fragmented to be the object of analysis that do not necessarily reflect the whole.

\section{IN ADDITION TO THE DOMINANT CONCEPTION OF HUMAN RIGHTS}

Since 1948, the United Nations adopted the Universal Declaration of Human Rights, and with it a plethora of rules, processes and institutions to define and protect human rights. Today almost all the causes they seek to translate in the language of rights. But even so, this universal adherence to the language of rights could not create a common ground and a possible agreement on the scope, content and philosophical basis of human rights.

It must point to the same twentieth century enshrining human rights was marked by two world wars and the absolute horror of genocide constituted as a political and economic project, with the accumulation of refugees, victims of persecution of ethnic minorities, and remained haunted front emergence of mass denationalization caused by totalitarian movements. That century had its becoming affected by a sequence of genocidal massacres of Germany to Rwanda, Armenia to Cambodia, beyond the horrors of ethnic cleansing practiced in Bosnia. People die of hunger in Haiti, Iraq, Afghanistan, Africa and other parts of the globe. 
Thus, the "human rights" expression, which historically is a cry for freedom, equality and brotherhood of all mankind, it is revealed paradoxical and, in fact, the culmination of an idealism considered by many as naive or cynical hypocrisy when confront oppressors, victims of war and the spectators who are faced with a situation in which the era of rights coexists with the "age of extremes", a term coined by Hobsbawm (1994) or, as stated Barretto:

[...] The one hand, proclaim in various legal texts a growing number of civil, political, social, economic and cultural rights, which are, in the history of law, the most complete affirmation of man's belief in his own dignity; on the other hand, those rights are transformed into utopian ideal, in that they are consistently violated by governments and social groups. (Barretto, 2013, p.32).

On the other hand, is Woodwiss (2006, p. 33) who states that, to the extent that the Western powers, that sponsor most of the development, have accepted the possibility that human rights must be legally applied, only because they feel now they have little to fear and much to gain on this application. For the author, it is because not only the disappearance of a major political competitors, the Soviet Union, but also because to the success of other Western initiative, namely the establishment of the doctrine of "justiciability' - the idea that only those rights civil and political, without costs, allegedly they are or should be immediately executed by a court. Thus, for the author legalization becomes a cause for concern to the extent that the price paid for it includes the neglect of both the economic and social rights as to the world cultural variety.

Several states, notably the former Soviet Union, abstained from voting on the Universal Declaration of Human Rights because they felt that the idea of a common humanity had been kidnapped by supporters of a particular ideology called "bourgeois individualism". Subsequently, people of color, women, ethnic and sexual minorities, developing and non-Western cultures more generally countries also found or felt they were excluded from the concept of universal rights of human rights on common humanity.

Donnelly (2006, p. 68), in a clearly normative approach, refers to the legalization of human rights and their normative force. The author presents an overview of global scope that differently, does not consider, for example, among others, the contextual element of historical social order related to human rights legalization process.

The reasons given by Donnelly (2006) are particularly related to the question of ratification of the main international instruments of human rights, leading to an international legal consensus on legalization. Thus, human rights defenders possess an international reference standard to help, with legitimacy in both nationally and internationally ways. Apart from the resulting changes.

This position contrasts with the "historic" and "discourse" approach of human rights proposed by Issa Shivji, which highlights the ideological component of human rights. It being understood that it is the main criticism made by Shivji $(1989$, p. 02) to the historical process of constitution and the adoption of the Universal Declaration of Human Rights by several countries that have promoted a colonial rule policy. This made the obliteration of the right of peoples to self-determination. The alternative proposed by the author for the human rights discourse can serve the recognition of collective subjects of human rights, necessarily goes through a reconceptualization process of human rights in order to be constituted as an ideological element of resistance. 
Mutua (2002, p.10) considers that the human rights movement is marked by a very own metaphor, and that is related to a parallel subtext and linked to major historical narrative of human rights, which depicts a relationship between offenders, victims and saviors. This colonialist construction (violators - victims - saviors) is considered a threedimensional metaphor in which each dimension reveals a metaphor itself. For the author, this three-dimensional representation of the bodies of human rights and its speech would prove as unidirectional and predictable; a dichotomous construct that necessarily puts what is regarded as "good" and what is considered "bad."

In this sense, behind the justice discourse, human rights, democracy, development, and even multiculturalism in modern rhetoric, underlies colonial logic of a Eurocentric epistemology; namely a standard of knowledge that is imposed as universal and categorizing of humanity. Logic that this is supported by the idea that some (the rescuers) are in a universal place, so that they are representing the considered universal knowledge (adequate, impartial, fair, good for all). On the other hand, the "other" (violators-victims) are those that are in a particular place and located and therefore should receive this knowledge. Thus, it is possible to find parities in epistemic control that allowed the development of concepts such as inferior peoples, barbaric, primitive and underdeveloped.

The first dimension of this prism comprises the wild and barbarous evokes images. The acts performed by the violators of human rights are presented as cruel and unimaginable, that it is represented as the negation of humanity.

In Mutua's point of view $(2002$, p. 10) the history of human rights shows the status as the classic rapist, a wild permanently committed to consume humans. Although the violation, the human rights discourse involves much more than solely the state, this is portrayed as an operational instrument of rights violations.

The states become violators (wild) when suffocate and oppress civil society. The "good" state controls its oppressive tendencies, purifying and internalizing human rights. The "bad" state, in turn, is expressed by an anti-liberal, anti-democratic or authoritarian culture. The state of redemption depends merely its submission to human rights standards. The state is the guarantor of human rights; it is also the target and the raison d'être of human rights standards.

But the reality is much more complex. While the metaphor may suggest, is not the state itself that constitutes a rapist or barbaric, but their cultural background. According to Mutua (2002, p.11), the state only becomes a violator of rights when the "bad" culture exceeds or does not allow the development of "good" culture. Thus, the "real" rapist is not the state itself, but a skewed culture of human rights.

The intrinsic savagery, both theoretically and practically, the one-party state, the military junta, the state controlled and closed, the theocracy, or even that revealed in cultural practices such as female genital mutilation are not the state itself. The state as such is neutral, instrumental - a receptacle - that violates rights insofar it implements the project of a culture of violations.

The second dimension of the prism presents the profile of the victim, as the essence and the idea of victimhood. The victim is a human being whose dignity and value have been violated by the rapist. The figure of the victim is a helpless, innocent whose natural attributes have been negated by the primitive and offensive actions of the state or the cultural foundation of the state. Why the structure of human rights is at the same time, against disasters and reconstructive. It is against disasters because it is designed to prevent more disasters by creating more victims. Reconstructive because it seeks to restructure 
the state and society to reduce the number of victims to identify them and prevent the conditions that give rise to them. The classic document of human rights reflects these two strategies that are mutually reinforced.

Important to stress that the concept of modernity was developed, at first, by given the contrast with the notion of "primitive", represented not only by the past, but also by other newly discovered, leading to the need to overcome, consummated by illustration. This passage from a lower to a higher state condition, are to Mignolo (2010), ilk for establishing the European epistemic dominance. In this context it is certain that, as ponders Mendieta (Apud Dussel, 2005), the production of knowledge implies the existence of individuals in power to state them and others that they are subjected to, that is, limited to mere position spectators when not relegated to the status of objects of knowledge. At this juncture, some have epistemic credibility (saviors) and others do not have standing to theoretical reflections considered as valid (rapist-victim).

The third dimension of the prism, according to Mutua (2002, p. 11), is represented by the savior or redeemer, the "good angel" which protects, vindicates, civilization, retain and safeguard. The savior is the bulwark of the victim against tyranny. The simple, yet complex, savior's promise is freedom: freedom from state tyrannies, tradition and culture. But it is also the freedom to create a better society based on particular values. In the history of human rights, the savior is the corpus of human rights itself, with the UN, Western governments, NGOs and Western charities like the real saviors, redeemers of an ignorant and cruel world.

Mutua (2002, p. 12) considers that these institutions, in fact, are mere fronts, to the extent that the savior is, ultimately, the whole set of rules and culturally based practices undeniably inherent in thinking and philosophy liberal, a rule of law. This corpus of human rights, for the author, is fundamentally Eurocentric and it follows a series of basic and interdependent failures that are perceived in the metaphor violators-victimssaviors. Legal systems and their philosophical bases show directly influenced by this situation.

The official perception of human rights, present in the traditional doctrine of History and Philosophy of Law, is manifested marked by this European liberal theory, which corroborates the theoretical and political elements required for the establishment of national states, or in the context of economic relations and policies of the period, the colonial powers (Quijano, 2005).

\section{THE (RE) CONSTRUCTION OF SPEECHES BY OTHERNESS, INTERDEPENDENCE AND HUMAN MUTUALISM}

There are several research groups that bring the issue of Human Rights called critical multiculturalism. Among these groups, Sousa Santos is one of which relate to diatopical hermeneutics and the concept of homeomorphic equivalents, proposed by Panikkar (2002). The initial and fundamental assumption lies in the use of these concepts is not reduced to a simple technique of interpretation, but that this theoretical framework is the product of a particular hermeneutic philosophy, whose main focus is intercultural dialogue. Panikkar is one of the exponents of this philosophical movement, calling itself "intercultural philosophy".

From this fundamental assumption instrumental, Santos can identify three sources of dialectical tensions that affect greatly, not only interpersonal relations in Western 
modernity in all its social spectrum, as well as the human rights policy since the end of the last century.

The first source among them correspond to the dialectical tension between what the author calls "social regulation and social emancipation", setting limits and transcend the limits towards the advances in the social field. Since the late twentieth century, this tension would have lost their creative potential, in that "the emancipation ceased to be the other of regulation to become the double regulation" (Santos, 2001, p.1). From the beginning of the twentieth century until their mid emancipatory mobilizations were direct consequences of regulatory crises and have resulted in the strengthening of emancipatory politics nowadays both the state crisis - either as a regulator or as welfare state - as well as the social emancipation of crises - epitomized, according to Santos (2001), the crisis of the social revolution and socialism taken as a standard of radical social transformation - are simultaneous and feed each other. In the same way, the politics of Human Rights, which was both a regulatory policy and an emancipatory politics, is caught up in this dual crisis, at the same time is a sign of the desire to overcome it.

The second dialectical tension lies in the relationship between the state and civil society. According to Santos, the state of modernity, even if present in a minimalist way, is virtually a maximalist state, to the extent that civil society, set to the other state, itself reproduces through originate laws and regulations of own state apparatus and which do not appear to be limits, since the legislative procedures respect the democratic rules set by the State. Santos even points out the issue of human rights as the core voltage:

[...] While the first generation of human rights (civil and political rights) was conceived as a struggle of civil society against the state, considered as the main potential violator of human rights, second and third generation (economic rights and social and cultural rights, quality of life, etc.) assume that the state is the main guarantor of human rights. (Santos, 2001, p.2)

Finally, Santos believes that the third dialectical tension befalls the friction between the nation state and the phenomenon called globalization. The political model practiced in Western modernity is one characterized by a basic unit framework, sovereign nation-states, who live in an international inter-state system, formed by sovereign States also. Santos (2001, p.3) notes, however, that the interstate system has always worked in some anarchic way, regulated by a very indelible authority, and "even the internationalism of the working class has always been more an aspiration than a reality".

Today, with the intensification of globalization which leads to a depletion of the nation-state model, the question that arises is to assert whether both social regulation and social emancipation, walk towards that same global scale. To what extent this process it is necessary to give and what fundamental weights to give support to this same movement? If, on the one hand, is already happening, with all the evidence, to speak of global civil society, global government and global equity and the bulwark of this process is necessarily the worldwide recognition of human rights policy, on the other vertex has -if the conflict of a fact that comes as a provocation to thought. In summary, both violations of human rights as the struggles in defense of them continue to envolve a decisive dimension which has not yet supranational, and in return, as well points Santos (2001), the positions adopted in relation to human rights continue to be product of specific ethos. 
On the other hand, Santos says is essential to acknowledge and accept the incompleteness of cultures and this can be done by diatopical hermeneutics that seek to "expand the maximum mutual incompleteness of consciousness through a dialogue that takes place, so to speak, with one foot in culture and another in another. "(SANTOS, 2001, p. 21). More than that, taking into account such consideration, you can use the diatopical hermeneutics as proposed by Pannikar to make use of strong topoi of certain crops in order to balance and weigh the shortcomings of others, that give rise to inequalities, exploitation and exclusion, to promote the strengthening and effectiveness of Human rights. This is the case of individualism, celebrated as an achievement of modernity and, paradoxically, the root of the problems of modern society.

Without losing sight of hermeneutics diatopical proposed by Panikkar (2002), it is argued that the spaces where people become individual in a perennial becoming, considered in their belonging to a collective, it contained a sense close to the meaning of the Greek word ethos, like it appears not in Plato or Aristotle, but a thinker originating as Heraclitus: éthos anthropous Daimon, or "the abode of man, the extraordinary". There are two thoughts originating - the communalist philosophy or community and that corresponding to the pre-Socratic worldview. Such insights that is urgent and necessary (re) assimilate.

That labor has been largely advanced by Lèvinas, for whom ethics has absolute priority over ontology - positioning that marks his distance from the Heidegger's vision, and sought to regain the vigor of ethics as the study of the condition possibility of the human being is open to the Other, in a therein where you can meet. It is possible to envision this proposal as a way to respond proactively to the exacerbated and sometimes predatory individualism, that seems to be prevalent in modern times.

The approach advocated by humanism of the other man philosopher, is that subjectivity cannot be conceived as a pure substance or monad moral. The human being - something-for-itself (quite different, so the thing-in-itself Kantian) - reveals the ability to enter transcendence in immanence, thought of as only way this overcome the ego closed itself (solipsist) and mind the alter, in short, the I become responsible for the effective fulfillment of the moral law on the third:

Kindness without any interest: others in their prayer, which is an order, as another face, another that I "respect" ["me regarde"], even when not looking at me, the other as close and always strange - kindness as transcendence; and I, the one who is obliged to respond, the irreplaceable and thus the elected and thus truly unique. Kindness to the first coming, man's right. Right other man before all (Levinas, 1997, p. 266).

Given the importance of otherness in the self-recognition, selfupdate and moral development, human relationships is vital to the consolidation and effectiveness of human rights from a communalist perspective. It is the community that defines a person and enables that person to meet through the instruments of human relationships. Thus, there must be a delicate balance between individual autonomy and the role of society in personal life that preserves the other in his otherness, in their uniqueness, without it departs.

\section{CONCLUSION}

Relativize the role of European Modernity and admit the relevance of ideas, struggles, thoughts and stories beyond the official settings is the first but not the only step 
to another formulation of the discourse hitherto considered unique and universal human rights. For this, you have to critically reflect on the various nuances of this discourse, through its theoretical foundations.

The theoretical foundations of the dominant discourse of human rights has been the subject of extensive research, which, at first, might suggest that the discussion on this subject was already exhausted and therefore does not deserve greater contributions. These conceptions about the human rights foundations, usually rest in some incontrovertible premises. Human Rights are considered as observed throughout this trial, either as a consequent unfolding of liberal thought, either as a product of European political struggles of modernity, with the basic reference classical liberalism and their individual freedom of ideas and formal equality. What characterizes this tradition is the appreciation of individuals, legally considered, by granting rights that flow of individual autonomy and free will of the year, due to its rationality.

Rethinking human rights means considering the idea of human rights as the product of an inclusive and global development, to consider the existence and participation of more than a social actor and enabled a society whose sign is the solidarity and tolerance in the process.

This preparation includes necessarily a multiplicity of actors whose contribution both culturally and socially, will be of fundamental importance to change the design, the direction and human rights goals.

\section{REFERENCES}

ARENDT, Hannah. Da revolução. Tradução Fernando Vieira. Brasília: Editora Universidade de Brasília, 1988.

BARRETTO, Vicente. O fetiche dos direitos humanos e outros temas. $2^{\mathrm{a}}$. ed., Porto Alegre: Livraria do Advogado, 2013.

CASTORIADIS, Cornelius. As encruzilhadas do labirinto. vol. 1, Tradução Carmen Sylvia Guedes e Rosa Maria Boaventura. Rio de Janeiro: Paz e Terra, 1987.

DONNELLY, Jack. The Virtues of Legalization. In: Meckled-García, Saladin and CALI, Basak (Ed.), The Legalization of Human Rights: Multidisciplinary Perspectives on Human Rights and Human Rights Law. New York: Routledge, 2006, p. 67-80.

DUSSEL, Enrique. Europe, modernity and Eurocentrism. In: LANDER, Edgardo (Org). The coloniality of knowledge: Eurocentrism and social sciences. Latin American perspectives. Buenos Aires: Colección Sur Sur, CLACSO, 2005.

FERREIRA FILHO, Manoel Gonçalves. Declaração de direitos do bom povo da Virgínia, Junho 16, 1776. São Paulo: Saraiva, 1978.

GIACOIA JUNIOR, Oswaldo. O projeto político da modernidade está esgotado. Instituto Humanitas Unisinos. Acesso em: 13 jan. 2016. Disponível em: <http://www.ihu. unisinos.br/noticias/noticias-anteriores/36309-\%60\%60o-projeto-politico-damodernidade-esta-esgotado $\% 60 \% 60>$.

HOBSBAWM, Eric. (1994). The Age of Extremes: the history of the world, 1914-1991. New York: Pantheon Books, 1994.

LEVINAS, Emmanuel. (1997). Entre nós: ensaios sobre a alteridade. Tradução P.S. Pivatto. Petropolis: Voices, 1997. 
MIGNOLO, Walter D. Epistemic Disobedience: Rhetoric de la Modernity, Logic y la colonialidad Grammar la Descolonialidad. Buenos Aires: Ediciones del Zodiac, 2010.

MUTUA, Makau. Human rights: a political and cultural critique. Philadelphia: University of Pennsylvania Press, 2008.

UNITED NATIONS. Universal Declaration of Human Rights, 1948.

PANIKKAR, Raimon. Is the notion of human rights in western concern? In: Interculture, 27 (1), Cahier 82, 2002, p. 28-47.

QUIJANO, Anibal. Coloniality of power, Eurocentrism and Latin America. In: The coloniality of knowledge: Eurocentrism and social sciences. Latin American perspectives. LANDER, Edgardo (Org). Buenos Aires: Colección Sur Sur, CLACSO, 2005, p.227-278. SANTOS, Boaventura de Souza. A Gramática do tempo: para uma nova cultura política, 3. ed., 1. reimp., São Paulo: Cortez, 2010.

SHIVJI, Issa G. (1989). Perspectives on human rights: an introduction. Acesso em: 13 jan. 2016. Disponível em: <http://rightstraining.fahamu.org/ocw/learning-for-change/ introduction-to-human-rights/content/pdf $>$.

WOODWISS, Anthony. (2006). The law cannot be enough: human rights and the limits of legalism. In: CALI, Basak; MECKLED-GRACÍA, Saladin (Orgs.). The legalization of human rights: multidisciplinary perspectives on human rights and human rights law. 1 ed., USA: Routledge, 2005.

Recebido em: 27 de abril de 2016.

Aprovado em: 17 de maio de 2016. 